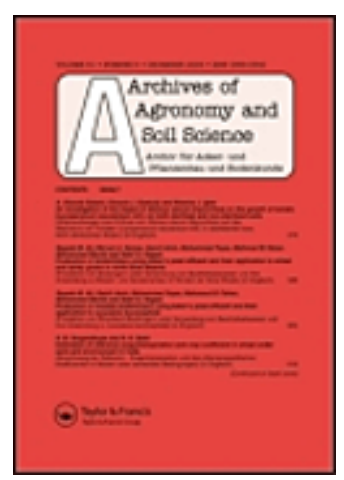

\title{
Comparison of methods for evaluating the suitability of Vertisols for Gossypium hirsutum (Bt cotton) in two contrasting agro-ecological regions
}

\begin{tabular}{|r|l|}
\hline Journal: & Archives of Agronomy and Soil Science \\
\hline Manuscript ID & GAGS-2018-0638.R2 \\
\hline Manuscript Type: & Original Article \\
\hline Keywords: & $\begin{array}{l}\text { Agro-ecological regions, Land suitability evaluation, Soil quality index, } \\
\text { Vertisols, Principal component analysis }\end{array}$ \\
\hline \multicolumn{2}{|l}{} \\
\end{tabular}

\section{SCHOLARONE \\ Manuscripts}




\title{
Comparison of methods for evaluating the suitability of Vertisols for Gossypium hirsutum (Bt cotton) in two contrasting agro-ecological regions
}

\author{
Karunakaran Karthikeyanª, Duraisamy Vasuª, Pramod Tiwarya, Andrew M. Cunliffeb, Padikkal \\ Chandran ${ }^{\mathrm{a}}$, Sankar Mariappan ${ }^{\mathrm{c}}$, Surendra K Singh ${ }^{\mathrm{d}}$
}

\begin{abstract}
aDivision of Soil Resource Studies, ICAR-National Bureau of Soil Survey and Land Use Planning, Nagpur, India; bSchool of Geography, College of Life and Environmental Sciences, University of Exeter, Exeter, UK; 'ICAR-Indian Institute of Soil and Water Conservation, Dehradun, India; ${ }^{\mathrm{d} I C A R-N a t i o n a l ~ B u r e a u ~ o f ~ S o i l ~ S u r v e y ~ a n d ~ L a n d ~ U s e ~ P l a n n i n g, ~ N a g p u r, ~ I n d i a ~}$
\end{abstract}

CONTACT: Karunakaran Karthikeyan; Division of Soil Resource Studies, ICAR-National Bureau of Soil Survey and Land Use Planning, Nagpur, India; Email:

\section{mailtokarthik77@gmail.com}

\begin{abstract}
Cotton (Gossypium sp.) is a major crop grown under rainfed conditions in Vertisols and associated soils in semi-arid tropical (SAT) regions of Peninsular India. In recent years, cotton productivity has declined due to various biophysical factors including pest and diseases, seasonal water stress soil degradation and poor crop management practices. In this study, we compare two methods for evaluating the suitability of Vertisols for cotton in contrasting two agro-ecological regions viz., sub-humid moist (SHM) region and semi-arid (SAD) were characterized. Twelve cotton growing Vertisols (seven from SHM and five from SAD) were evaluated for their suitability for cotton cultivation using soil quality index (SQI) and modified Sys-FAO method. SQIs were
\end{abstract}


calculated using the weighted additive index from transformed scores of selected indicators by principal component analysis. For Sys-FAO method both biophysical and soil characteristics were considered for suitability evaluation. We found that the soils of SHM region were moderately suitable for cotton cultivation with soil moisture as the major limiting factor, whereas the soils of $\mathrm{SAD}$ region are marginally suitable due to high exchangeable sodium percentage and poor hydraulic conductivity. From this, it may be concluded that the weighted SQI has better agreement with the cotton yield.

Keywords: Land suitability evaluation; soil quality index; Vertisols; principal component analysis

\section{Introduction}

Globally, Vertisols and vertic intergrades cover ca. 308 million ha (USDA-SCS 1994). These soils occur under all temperature and moisture regimes, but predominantly in tropical (ca. 60\%) and sub-tropical (ca. 30\%) climates (Ahmad 1996; Coulombe et al. 1996; Dudal and Eswaran 1988). In India, these soils occur ca. $76.4 \mathrm{~m}$ ha, covering $23 \%$ of the total land area (Mandal et al. 2014). Vertisols and associated soils in central and western parts of India are popularly known as 'Black Cotton Soils', due to their historic use for cotton production. India is the largest cotton producing country in the world, followed by China and USA (DCD 2017; ICAC 2017).

Over recent decades, the cotton productivity in the semi-arid tropical (SAT) regions of India has declined due to soil degradation caused by increasing sodicity (exchangeable sodium percent 15-40), degrading soil structure, impaired drainage and poor crop management practices (Balpande et al. 1996; Vaidya and Pal 2002; Kadu et al. 2003). These issues have been compounded by inappropriate crop management practices such as lack of moisture conservation practices and pest control strategies under rainfed agriculture (Kadu et al. 2003; Blaise and Ravindran 2003, 
Choudhary and Gaur 2010), and rainfall variability with mid-season dry spells during the crop growth (Tripathi et al. 1990; DCD 2017).

Sustaining cotton production is, therefore, an important challenge for contemporary farming systems. Knowledge of soils, climatic conditions, and crop requirements for particular crop is an essential pre-requisite for optimizing management practices to sustain crop production (Sys 1985; Van Ranst et al. 1996). Vertisols are vulnerable to degradation when the climatic change phenomenon (humid to semi-arid in plio-pleistoscene) made the soil bio-physical factors to less desirable conditions for agriculture (Srivastava et al. 2015; Pal et al. 2016). For example, reduction in mean annual rainfall (MAR) can lead to the formation of calcareous and alkaline soils with elevated $\mathrm{pH}$ and calcium carbonate contents (Pal et al. 2012). However, Bhattacharyya et al. (2016) found that the chemically degraded Vertisols can be highly receptive to management interventions, such as amelioration with gypsum and irrigation with good quality water. In the SAT regions, Vertisols vary from Typic Haplusterts in humid tropical, Typic/Udic Haplusterts in semi-arid moist, and sub-humid dry climates and Sodic Haplusterts and Sodic Calciusterts in semi-arid dry (SAD) and arid dry climates (Pal et al. 2009).

The appropriate uses of Vertisols with varying physical and chemical properties need to be evaluated to optimize sustainable land management. Many approaches have been developed to evaluate the soil site suitability, such as FAO land evaluation method (FAO 1976), Storie index (Storie 1978) and parametric approach (Sys et al. 1991). For evaluating tropical soils, Naidu et al. (2006) proposed a modified Sys methodology. Evaluating agricultural land suitability involves the consideration of edaphic, climatic, agronomic, and physiographic variables. All these factors contribute differently to the suitability evaluation and yet approaches for integrating these diverse factors for land suitability evaluation are inconsistent. In recent literature, multi-criteria decision analysis (MCDA) is considered as an effective approach to perform land suitability evaluations, 
since these frameworks combine information from several criteria to form a single index optimized for a specific objective (Malczewski 2006; Cinelli et al. 2014; El Baroudy 2016). Among the different MCDA approaches, soil quality index (SQI) method to evaluate land suitability is recently used in many studies due to its quantitative nature (Mukherjee and Lal 2014; Biswas et al. 2017). Considering both surface and subsurface properties, SQI helps to identify the soil properties having maximum influence on crop performance in a particular region. In this context, the present study was undertaken to compare Sys land evaluation method with SQI method in order to find most suitable method for evaluating the Vertisols for cotton suitability in two different bio-climatic regions of India. The objectives of the study were (i) to evaluate soil-site suitability of Vertisols; (ii) to compare Sys soil suitability index and SQI method for suitability evaluation and (iii) to study the relationship between soil site suitability and cotton yields.

\section{Materials and Methods}

\section{Study sites}

The two sites for the present study were (i) Dhar, Madhya Pradesh, and (ii) Thimmajipet, Telangana, which have contrasting agro-ecological conditions viz., sub-humid and semi-arid climates, respectively (Figure 1). The soils of both sites were developed from basaltic parent materials (Singh and Murti 1975; Pal et al. 2012), The biophysical characteristics of the study sites are presented in Table 1.

\section{Soil sampling}

Twelve representative pedons were sampled in cotton growing soils, seven from Dhar area and five in Thimmajipet area. These soils have been under Bt cotton cultivation for more than 15 years, according to the official land records of Tehsil office, corroborated by interviews with the land owners. At each site, a soil pit was dug exposing a $150 \mathrm{~cm}$ deep soil profile, and was described 
according to the soil taxonomy (Soil Survey Staff 2014). Samples were collected from each horizon using a trowel and stored in polythene bags and transported to the laboratory. The samples were air dried and sieved through $2 \mathrm{~mm}$ sieve prior to further laboratory analysis.

\section{Analysis for physical and chemical soil properties}

Particle-size distribution was determined using the pipette method (Mehra and Jackson 1960). Sand $(2000-50 \mu \mathrm{m})$ and total clay $(<2 \mu \mathrm{m})$ fractions were separated after dispersion according to the size segregation procedure (Jackson 1979). Bulk density was measured by the core method (Blake and Hartge 1986) and the porosity of the soil was calculated assuming soil particle density of $2.65 \mathrm{Mg} \mathrm{m}^{-3}$. Saturated hydraulic conductivity was determined by constant head method (Klute and Dirksen 1986). Soil water retention at both field capacity and the permanent wilting point was measured using a pressure plate apparatus at a suction of 0.033 and $1.5 \mathrm{MPa}$, respectively (Cassel and Nielsen 1986), and available water content (AWC) was calculated by subtracting water content at permanent wilting point from water content at field capacity. Soil $\mathrm{pH}$ was measured with 1:2 soil/water ratio (Jackson 1979). Electrical conductivity (EC) was determined by conductivity bridge (Richards 1954). The organic carbon content of the $<2 \mathrm{~mm}$ particle size fraction was determined using the modified Walkley and Black method (Jackson 1973), although $>2 \mathrm{~mm}$ particle size fractions can sometimes contain non-trivial amounts of organic carbon (Cunliffe et al. 2016). Calcium carbonate equivalent was determined by the rapid titration method described by Piper (1966). Cation exchange capacity (CEC) was determined by saturating the soil exchange complex with $\mathrm{Na}$, which was subsequently displaced by $\mathrm{NH}_{4}{ }^{+}$from $1 \mathrm{~mol} \mathrm{~L}^{-1} \mathrm{NH}_{4} \mathrm{OAc}$ solution, and the $\mathrm{Na}$ in the extract was measured by using atomic absorption spectrophotometer (Richards 1954). Exchangeable $\mathrm{Ca}$ and $\mathrm{Mg}$ for non-calcareous soil were extracted using $1 \mathrm{~mol} \mathrm{~L}^{-1}$ neutral $\mathrm{NH}_{4} \mathrm{OAc}$ (Lanyon and Heald 1982) and for calcareous soils KCl-TEA was used (Soil Survey Staff 2014) and determined by Inductively Coupled Plasma Atomic Emission spectrometer (ICP- 
Prodigy, Teledyne, USA). Exchangeable $\mathrm{K}$ and $\mathrm{Na}$ were determined by emission spectrometer of $1 \mathrm{~mol} \mathrm{~L}^{-1} \mathrm{NH}_{4} \mathrm{OAc}$ extracts (Thomas 1982). Clay CEC was calculated by using the formula $(\mathrm{CEC} /$ clay $) \times 100$. Base saturation was calculated as the ratio of total bases to CEC. Exchangeable sodium percentage (ESP) and exchangeable magnesium percentage (EMP) were estimated as the ratio of sodium, magnesium to the sum of the exchangeable bases, respectively. Weighted average soil properties were calculated for two depths: (i) $0-30 \mathrm{~cm}$ depth (surface) and ii) $0-100 \mathrm{~cm}$ depth (soil control section).

\section{Soil-site suitability}

The soil-site suitability for cotton cultivation is derived from a combination of soil-landscape (static) and soil (dynamic) properties. The climate and landscape properties include MAR, topography, slope, erosion and these factors directly influence the physical and chemical properties of the soil and thus influence the soil quality. For developing a soil-site suitability criteria for cotton, the procedure advocated by FAO was followed viz., (i) characterization of existing soil, climatic and land use conditions, (ii) development of soil-site criteria (iii) matching the crop requirements with the existing soil and climatic conditions, and (iv) determining the soil-site suitability for cotton (FAO 1976). Soil-site suitability for cotton was evaluated based on the criteria given by Naidu et al. (2006), which is a modification of FAO method (FAO 1976), Sys (1985) and NBSS\&LUP (1986). The soil suitability for cotton cultivation of the whole soil profile $(0-150 \mathrm{~cm})$ was classified according to criteria presented in Error! Reference source not found..

\section{Soil quality index}

Soil quality index (SQI) is an effective tool to support decision-making in crop production systems. SQIs are derived from the minimum data sets which are selected according to the defined

soil function and management goals. Most soil quality evaluation studies have focused on the properties of near-surface $(0-30 \mathrm{~cm})$ layers (Liebig et al. 2001; Cambardella et al. 2004; Karlen et 
al. 2008) with few exceptions where subsurface properties also considered (Merrill et al. 2012, 2013; Moncada et al. 2014; Ray et al. 2014). Vasu et al. (2016) established the importance of subsurface soil properties while evaluating crop (Zea mays, Cajanus cajan and Gossypium hirsutum) productivity and soil quality relationship by SQI. In the present study, SQI was derived based on the methodology outlined by Andrews et al. (2002), and we followed three steps for SQI evaluation: (i) selection of key indicators for a minimum dataset (MDS), (ii) scoring the indicators, and (iii) calculating the SQI for two depths: (i) 0-30 cm depth (near surface), and (ii) 0-100 cm depth (rooting zone/soil control section).

\section{Indicators of minimum dataset (MDS)}

Principal component analysis (PCA) was performed on 17 physical and chemical soil properties to identify the minimum datasets that would be used for developing soil quality indices. PCA reduces the data dimension without losing information (Armenise et al. 2013). The eigen values shows the relative contribution of a principal component (PC) to the total variance, and PCs with eigen values $\geq 1$ were retained (Andrews et al. 2002). The PCs selected were subjected to varimax rotation to enhance the variability of the components. Under each PC, highly weighted variables were selected (within $10 \%$ of the highest factor loading) and further multivariate correlation co-efficient was used to check the redundancy and correlation between the variables. If the variables were highly correlated $(r>70 \%)$, then parameters with the highest loading factor (as absolute value) were retained as soil quality indicators (Anderson-Teixeira et al. 2011; Chen et al. 2013).

\section{Scoring the Identified Indicators}

All the selected indicator values were transformed using linear scoring functions with respect to their contribution to soil functions. Each indicator was scored using one of the following curves: (i) "more is better" (upper asymptotic sigmoid curve) indicators of each observation 
divided by the highest observed value such that the highest value received a score of 1 (ii) "less is better" (lower asymptotic sigmoid curve) the lowest observed value divided by each observation, such that the lowest observed value receives a score of 1 and (iii) "midpoint optimum" (Gaussian curve bell-shaped curve) where higher is better up to an optimum threshold value (e.g. $\mathrm{pH}$ 6.5) then the score decreases again with distance from the threshold (Wymore 1993; Liebig et al. 2001).

\section{Soil quality index calculation}

The soil quality indicator scores were integrated into indexes through weighted additive index approach, from the weightage based on the PCA for both the depth i.e., near-surface $(0-30 \mathrm{~cm})$ and the cotton rooting zone $(0-100 \mathrm{~cm})$. Each PC explained a certain amount $(\%)$ of the variation in the total dataset (Andrews et al. 2002). The total percentage of variance from each PC was divided by percentage of cumulative variance to derive the weightage factor (Ray et al. 2014). The derived weightage factor was used for selected soil parameters from PCs. In the case of uncorrelated soil parameters within a PC, weightage factors were equal to the percentage of total variance explained by the PC standardized to unity. For correlated indicators, the percentage of the total variance explained by the PC was divided among these and then standardized to unity (Masto et al. 2008). Weighted mean of the MDSs was calculated for both the depths i.e., 0-30 cm and 0$100 \mathrm{~cm}$ and subsequently the weighted mean of the SQI were derived for each profile. The calculated SQI values were correlated with the results of soil suitability analysis.

\section{Results and Discussion}

\section{Soil physical and chemical characteristics}

The descriptive statistics for the measured physical and chemical properties of soils from both the study areas are described in Tables 2 and 3. These data were used to develop SQI for assessing soil-site suitability. In both the study areas, coefficient of variation $(\mathrm{CV})$ were high $(>35)$ 
for saturated hydraulic conductivity, $\mathrm{CaCO}_{3}$, and $\mathrm{OC}$. However, in Dhar soils, EC, ESP, and sand content also had high $\mathrm{CV}$. These large $\mathrm{CV}$ values in soil properties may be due to both natural pedogenic processes and management practices (Rao and Wagenet 1985).

Among the various soil properties used for assessing the site suitability of Thimmajipet soils, ESP $(13.7-46.7 \%)$ appears to be more prominent factor that limit the crop production due to soil structural degradation (caused by high sodium along with the presence of magnesium) resulting in low saturated hydraulic conductivity $(\mathrm{sHC})\left(0.01-0.21 \mathrm{~cm} \mathrm{~h}^{-1}\right)$. In contrast, ESP was lower $(0.50-24 \%)$, and sHC was higher $\left(0.01-1.25 \mathrm{~cm} \mathrm{~h}^{-1}\right)$ in Dhar soils.

Cotton growth is generally affected by impeded drainage and these condition can be induced by high ESP and EMP (Bange et al. 2004).

Thimmajipet soils have more $\mathrm{CaCO}_{3}$ content than Dhar soils $(7.8 \%$ vs. $1.2 \%)$. This could be attributed to the pedogenic formation of $\mathrm{CaCO}_{3}$ in Thimmajipet soils where PET exceeds MAR (Pal et al. 2012; Vasu et al. 2017). Higher $\mathrm{CaCO}_{3}$ contents increase soil $\mathrm{pH}$ and reduce hydraulic conductivity, adversely affecting cotton yields (Seghal 1991; Kadu et al. 2003; Bhattacharyya et al. 2016). In Dhar soils, higher $\operatorname{MAR}(>1100 \mathrm{~mm})$ has resulted in soluble $\mathrm{CaCO}_{3}$ being translocated to the lower depth of soil by percolating water, resulting in low concentration of $\mathrm{CaCO}_{3}$ in the upper $100 \mathrm{~cm}$ of the soil. Soil $\mathrm{pH}$ was high (9.3 mean) in Thimmajipet soils, due to the presence of pedogenic $\mathrm{CaCO}_{3}$, whereas in Dhar it ranges from neutral to alkaline (7.6-9.0). Thus, $\mathrm{CaCO}_{3}$ does not constrain growth in Dhar soils, whereas in Thimmajipet soils, higher free $\mathrm{CaCO}_{3}$ content in the surface horizon modifies soil properties to make them chemically degraded (Bhattacharyya et al. 2016). Mean organic carbon was lower $(0.26 \%)$ in Dhar than the Thimmajipet $(0.48 \%)$. The CEC of the soils of both the regions are high due to the presence of smectite minerals (Pal and Deshpande 1987). 


\section{Soil site suitability assessment}

The soil-site suitability assessment (Naidu et al. 2006; supplementary information Table S2) showed the Dhar region soils were moderately suitable (S2) for cotton cultivation with soil moisture as the major limiting factor, whereas the Thimmajipet region soil were marginally suitable (S3) with comparatively more limitation due to soil (high ESP) and climatic parameters (lower MAR and higher PET). The differentiating characteristics identified with respect to the soil site suitability for cotton cultivation of the two regions is presented in table 4 .

\section{Soil quality assessment}

\section{Selection of minimum datasets}

From PCA results, four principal components (PCs) with eigen values higher than 1 were selected for indicator selection and the four PCs explained $84 \%$ of the total variability in soil properties (supplementary information Table S4). In PC1, silt, bulk density (BD), porosity, available water content (AWC), $\mathrm{pH}$, electrical conductivity (EC), exchangeable sodium per cent (ESP) and exchangeable magnesium per cent (EMP) were the highly weighed parameters. However, multivariate correlation showed significant relationship between these parameters (supplementary information Table S5) and hence BD was retained due to its highest loading factor. Apart from BD, $\mathrm{pH}$ and EMP were also included in MDS since these parameters significantly influence the growth of cotton in Vertisols, by affecting hydrologic properties of the soils. Clay, $\mathrm{CaCO}_{3}$ and $\mathrm{Ca} / \mathrm{Mg}$ ratio were chosen from $\mathrm{PC} 2$ and after correlation only $\mathrm{Ca} / \mathrm{Mg}$ was retained as MDS (Table S4). Saturated hydraulic conductivity was selected in PC3 (Table S3), as clay CEC is a derived parameter from clay and CEC values $(\mathrm{CEC} /$ clay $\times 100)$. Organic carbon was selected as an indicator from PC4. 
Thimmajipet receives approximately half the precipitation of Dhar. The greater aridity resulting from higher PET than MAR in Thimmajipet led to high $\mathrm{pH}$, ESP and EMP, formation of pedogenic $\mathrm{CaCO}_{3}$ which reduced the saturated hydraulic conductivity of the soils. The high ESP and EMP in these soils could be attributed to the presence of pedogenic carbonates (Pal et al. 2016). Impairment of hydraulic conductivity due to clay dispersion caused by high ESP and EMP was reported by Zade (2007) and Pal et al. (2016). Vasu et al. (2016) emphasized that ESP and saturated hydraulic conductivity has to be considered as effective indicators for assessing soil quality in Vertisols of SAT regions of India which are susceptible to faster degradation than their humid region counterparts (Wilding et al. 1963; Pal et al. 2016).

Thimmajipet soils, occurring in SAD region with high ESP (13.7- 46.6) and calcareousness are very hard when dry, adversely affecting crop growth. Optimizing the physical and chemical properties of the Thimmajipet soils to make them suitable for cotton cultivation would require (expensive) chemical amelioration measures (Pal et al. 2000; Bhattacharyya et al. 2016). The indicators selected for assessing SQI depend on both the requirements of particular crops, and the available data (Qi et al. 2009). Our results showed that while selecting soil quality indicators, consideration has to be given for inherent properties (little change over time) rather than the dynamic properties (changes with respect to soil management) as inherent properties have greater influence on soil functions (Juhos et al. 2016)

\section{Soil quality index}

The SQI was calculated from the MDSs indicator scores of each observation from both regions. SQI values $>0.57$ in the weighted additive index is considered as better (more than the mean value) (Table 6). The results showed that the weighted SQI of Thimmajipet soils were significantly higher than the average value $(\mu=0.57)$ irrespective of soil depth (Table 5). In Dhar region, the SQIs of the soils were less than the mean values except for pedon 5. The lower SQI values obtained for 
soils in Dhar region may be due to higher exchangeable magnesium percent (EMP) $(\mu=28.02)$ and bulk density $\left(\mu=1.6 \mathrm{M} \mathrm{g} \mathrm{m}^{-3}\right)$ (Table 3 ) and the higher SQI of Thimmajipet may be due to better aggregation and a positive $\mathrm{Ca} / \mathrm{Mg}$ ratio. Overall, $\mathrm{SQI}$ for both surface and sub-surface soils indicates Thimmajipet is better suited for cotton agriculture than the Dhar.

The SQI of both the depths are more or less similar and the nutrient content does not exhibit much variation among sites because nutrient content is heavily influenced by management practices. Hence, the nutrient related parameters were not considered for evaluating the SQI. As per the soil suitability criteria, Dhar soils were marginally suitable and Thimmajipet soils are unsuitable for cotton cultivation. However, according to the SQI, the soils of Thimmajipet region were classified as moderate to high in quality (Table 6). Contradictorily, the results of modified Sys method classified the Dhar soils with higher suitability class (S2) than Thimmajipet soils (S3). These results endorse the views of Sojka and Upchurch, (1999) who criticized the indicator based SQI approach as statistical dependent rather than accounting for the soil processes specific to the location. Hence we correlated the SQI values with the crop yield for the respective sites, and found that SQI was a stronger predictor of cotton yield in the Dhar region $\left(\mathrm{R}^{2}=0.83\right)$ compared to the Thimmajipet region $\left(\mathrm{R}^{2}=0.49\right)$ (Figure 2 ). Our findings are consistent with those of Vasu et al. (2016).

It is important to note that the higher scores of SQI of Thimmajipet soils had moderate/low correlation with yield $\left(R^{2}=0.49\right)$, but vice-versa the SQIs of Dhar soils were low $(\mu=0.57)$ but were more strongly correlated with yield $\left(\mathrm{R}^{2}=0.83\right)$ (Table 7$)$. SQI is a strong predictor of cotton yield within regions, but is a weak predictor across regions. Our findings support the arguments that site characteristics such as rainfall, slope, soil depth, length of growing period, stoniness and drainage must be considered when assessing soil-site suitability for crops.

\section{Conclusion}


The present study compared two methods (SQI and Sys index) for evaluating the suitability of Vertisols for cotton cultivation in contrasting agro-ecological regions. Results showed that the methods differ and produced contrasting results with respect to the crop suitability. Our analysis suggested that the inherent and dynamic properties of soils of Thimmajipet were modified due to climate driven pedogenic processes which result in poor conditions for the growth and development of cotton. The soils of Dhar region have comparatively better characteristics as the sub-humid climate with higher rainfall, which supports successful cotton cultivation. However, the SQI approach rated the Dhar soils lower than the Thimmajipet soils, which indicates that excluding important site-characteristics in suitability evaluations may lead to incorrect conclusions. Hence, we re-emphasize that if MAR, slope, soil depth, length of growing period are considered for suitability evaluation, the SQI could be used a promising tool for monitoring the changes in soil quality.

\section{Conflict of interests}

The authors declare no conflicts of interest regarding the publication of this paper.

\section{Acknowledgements}

We thank the reviewers and the handling editor for their constructive feedback, which helped us to improve over the earlier draft of this manuscript.

\section{References}


Ahmad N.1996. Occurrence and distribution of Vertisols, In: Ahmad N, Mermut A, (Eds.), Developments in Soil Science, Vertisols and Technologies for Their Management. Amsterdam: Elsevier; p. 1-41.

Anderson-Teixeira KJ, Delong JP, Fox AM, Brese DA, Litvak ME. 2011. Differential responses of production and respiration to temperature and moisture drive the carbon balance across a climatic gradient in New Mexico. Global Change Biol. 17:410-424.

Andrews SS, Karlen DL, Mitchell JP. 2002. A comparison of soil quality indexing methods for vegetable production systems in Northern California. Agric Ecosyst Environ. 90:25-45.

Armenise E, Redmile-Gordon MA, Stellacci AM, Ciccarese A, Rubino P. 2013. Developing a soil quality index to compare soil fitness for agricultural use under different managements in the Mediterranean environment. Soil Tillage Res. 130:91-98.

Balpande SS, Deshpande SB, Pal DK. 1996. Factors and processes of soil degradation in vertisols of the Purna Valley, Maharashtra, India. Land Degrad Dev. 7:313-324.

Bange MP, Milroy SP, Thongbai P. 2004. Growth and yield of cotton in response to waterlogging. Field Crops Res. 88:129-142.

Bhattacharyya T, Pal DK, Wani SP, Sahrawat KL. 2016. Resilience of semi-arid tropical soils. Curr Sci. 110:1784-1788.

Biswas S, Hazra GC, Purakayastha TJ, Saha N, Mitran T, Singha Roy S, Basak N, Mandal B. 2017. Establishment of critical limits of indicators and indices of soil quality in rice-rice cropping systems under different soil orders. Geoderma. 292:34-48. +

Blake GR, Hartge KH. 1986. Particle Density, in: Methods of Soil Analysis, Part 1: Physcial and Mineralogical Methods, Agronomy Monography. Madison, Wisconsin, USA: ASA and SSSA, p. 377-382. 
Blaise D, Ravindran CD. 2003. Influence of tillage and residue management on growth and yield of cotton grown on a Vertisols over 5 years in a semi-arid region of India. Soil Tillage Res. 70:163-173.

Cambardella CA, Moorman TB, Andrews SS, Karlen DL. 2004. Watershed-scale assessment of soil quality in the loess hills of southwest Iowa. Soil Tillage Res. 78:237-247.

Cassel A, Nielsen DR. 1986. Field capacity and available water capacity. In: Klute, A. (Ed.). Methods of Soil Analysis, Part 1: Physical and Mineralogical Methods. Madison, (WI): American Society of Agronomy, p. 901-924.

Chen YD, Wang HY, ZhouJM, Xing L, Zhu BS, Zhao YC, Chen XQ. 2013. Minimum Data Set for Assessing Soil Quality in Farmland of Northeast China. Pedosphere. 23:564-576.

Choudhary B, Gaur K. 2010. Bt Cotton in India: A Country Profile. ISAAA Series of Biotech Crop Profiles. Ithaca, NY: ISAAA.

Cinelli M, Coles SR, Kirwan K. 2014. Analysis of the potentials of multi criteria decision analysis methods to conduct sustainability assessment. Ecol Indic.46:138- 148.

Coulombe CE, Wilding LP, Dixon JB. 1996. Overview of Vertisols: characteristics and impacts on society, in: Sparks, D.L. (Ed.). New York, NY, USA: Adv. Agron. Academic Press, p. $289-375$.

Cunliffe AM, Puttock AK, Turnbull L, Wainwright J, Brazier RE. 2016. Dryland, calcareous soils store (and lose) significant quantities of near-surface organic carbon. J Geophys Res Earth Surf. 121:684-702.

[DCD] Directorate of Cotton Development. 2017. Status Paper of Indian Cotton. Government of India. 
Dudal R, Eswaran H. 1988. Distribution properties and classification of Vertisols. In: Wilding LP, Pueutes R, (Eds.). Vertisols Their Distribution, Properties, Classification and Management. College Station, Texas: Texas A\&M University Printing Center; p. 1-22.

El Baroudy AA. 2016. Mapping and evaluating land suitability using a GIS-based model. Catena.140:96-104.

FAO. 1976. A framework for land evaluation (No. Soils Bull. 32). Rome, Italy: FAO.

ICAC. 2017. March Cotton Report. International Cotton Advisory Committee.

Jackson ML. 1973. Soil Chemical Analysis. New Delhi: Prentice Hall of India.

Jackson ML. 1979. Soil Chemical Analysis-Advanced Course, 2nd ed. University of Wisconsin, Wisconsin, Madison.

Juhos K, Szabó S, Ladányi M. 2016. Explore the influence of soil quality on crop yield using statistically-derived pedological indicators. Ecol Indic. 63:366-373.

Kadu PR, Vaidya PH, Balpande SS, Satyavathi, PLA, Pal DK. 2003. Use of hydraulic conductivity to evaluate the suitability of Vertisols for deep-rooted crops in semiarid parts of central India. Soil Use Manage. 19:208-216.

Karlen DL, Tomer MD, Neppel J, Cambardella CA. 2008. A preliminary watershed scale soil quality assessment in north central Iowa, USA. Soil Tillage Res. 99:291-299.

Klute A, Dirksen C. 1986. Hydraulic conductivity and diffusivity laboratory methods. In: Klute A, (Ed.). Methods of Soil Analysis, Part 1: Physical and Mineralogical Methods. Madison: American Society of Agronomy, p. 687-734.

Lanyon LE, Heald WR. 1982. Magnesium, calcium, strontium and barium, in: Page AL, (Ed.). Methods of Soil Analysis, Part 2: Chemical and Microbiological Properties, Agronomy. Madison, Wisconsin, USA: ASA and SSSA, p. 247-262. 
Liebig MA, Varvel G, Doran J. 2001. A simple performance-based index for assessing multiple agroecosystem functions. Agron J. 93:313-318.

Malczewski J. 2006. GIS based multi criteria decision analysis: a survey of the literature, Int. J Geogr Inf Sci. 20:703-726.

Mandal C, Mandal DK, Bhattacharyya T, Sarkar D, Pal DK, Prasad J, Sidhu GS, Nair KM, Sahoo AK, Das TH, Singh RS, Srivastava R, Sen TK, Chatterji S, Chandran P, Ray SK, Patil NG, Obireddy GP, Mahapatra SK, et al. 2014. Revisiting agro-ecological sub-regions of India a case study of two major food production zones. Curr Sci. 107:1519-1536.

Masto RE, Chhonkar PK, Purakayastha TJ, Patra AK, Singh D. 2008. Soil quality indices for evaluation of long-term land use and soil management practices in semi-arid sub-tropical India. Land Degrad Dev. 19:516-529.

Mehra OP, Jackson ML. 1960. Iron oxide removal from soil and clay by a dithionate citrate system buffered with sodium-bi-carbonate. In: Clays Clay Miner. Presented at the Proc. 7th Conf. Natl. Acad. Sci. Natl. Res. Council Publ. p. 317-327.

Merrill SD, Liebig MA, Tanaka DL, Krupinsky JM, Hanson JD. 2013. Comparison of soil quality and productivity at two sites differing in profile structure and topsoil properties. Agric Ecosyst Environ. 179:53-61.

Merrill SD, Tanaka DL, Liebig MA, Krupinsky JM, Hanson JD, Anderson RL. 2012. Sequence effects among crops on alluvial-derived soil compared with those on glacial till-derived soil in the northern Great Plains, USA. Agric Syst. 107:1-12.

Moncada MP, Gabriels D, Cornelis WM. 2014. Data-driven analysis of soil quality indicators using limited data. Geoderma. 235:271-278.

Mukherjee A, Lal R. 2014. Comparison of soil quality index using three methods. PLoS One. 9:115. 
Naidu LGK, Ramamurthy V, Challa O, Hegde R, Krishnan P. 2006. Manual Soil-Site Suitability Criteria for Major Crops (No. NBSS Publication No. 129). Nagpur, India: NBSS\&LUPP.

NBSS\&LUP. 1986. The soils of Mondha village (Nagpur) for Agro-technology transfer, Soil Bull. II, ICAR- Nagpur, India: NBSS \& LUP.

Pal DK, Bhattacharyya T, Chandran P, Ray SK, Satyavathi PLA, Durge SL, Raja P, Maurya UK. 2009. Vertisols (cracking clay soils) in a climosequence of Peninsular India: Evidence for Holocene climate changes. Quatern Int. 209:6-21.

Pal DK, Bhattacharyya T, Sahrawat KL, Wani SP. 2016. Natural chemical degradation of soils in the Indian semi-arid tropics and remedial measures. Cur. Sci.110:1675-1682.

Pal DK, Dasog GS, Vadivelu S, Ahuja RL, Bhattacharyya T. 2000. Secondary calcium carbonate in soils of arid and semi-arid regions of India. In: Lal R, Kimble JM, Eswaran H, Stewart BA. (Eds.), Global Climate Change and Pedogenic Carbonates. Boca Raton, FL: CRC Press, p. 149-185.

Pal DK, Deshpande SB. 1987. Characteristics and genesis of minerals in some benchmark vertisols of India. Pedologie. 259-274.

Pal DK, Wani SP, Sahrawat KL. 2012. Vertisols of tropical Indian environments: Pedology and edaphology. Geoderma. 189:28-49.

Piper CS. 1966. Soil and Plant Analysis. Bombay: Hans Publisher.

Qi Y, Darilek JL, Huang B, Zhao Y, Sun W, Gu Z. 2009. Evaluating soil quality indices in an agricultural region of Jiangsu Province, China. Geoderma. 149:325-334.

Rao PSC, Wagenet RJ. 1985. Spatial Variability of Pesticides in Field Soils: Methods for Data Analysis and Consequences. Weed Sci. 33:18-24.

Ray SK, Bhattacharyya T, Reddy KR, Pal DK, Chandran P, Tiwary P, Mandal DK, Mandal C, Prasad J, Sarkar D, Venugopalan MV, Velmourougane K, Sidhu GS, Nair KM, Sahoo AK, 
Das TH, Singh RS, Srivastava R, Sen TK, Chatterji S. 2014. Soil and land quality indicators of the Indo-Gangetic Plains of India. Curr Sci.107:1470-1476.

Richards LA. 1954. Diagnosis and Improvement of Saline and Alkali soils (USDA Agriculture Handbook No. 60.). Washington, DC, USA: US Government Printing Office.

Sehgal JL. 1991. Soil site suitability evaluation for cotton. Agropedology. 1:49-63.

Singh GC, Murti GSRK. 1975. Mineralogy of a few basaltic soils of Madhya Pradesh. INSA Bull $50: 338-345$.

Soil Survey Staff. 2014. Soil survey methods manual (No. Soil Survey Investigations Report No. 42. Version 5.0). Washington, DC: USDA-NRCS.GPO.

Sojka RE, Upchurch DR. 1999. Reservations regarding the soil quality concept. Soil Sci Soc Am J. 63:1039-1054.

Srivastava P, Pal DK, Aruche KM, Wani SP, Sahrawat KL.2015 Soils of the Indo-gangetic plains: A pedogenic response to landscape stability, climatic variability and anthropogenic activity during Holocene. Earth Sci Rev. 140:54-71.

Storie R. 1978. Storie index soil rating. University of California Division of Agricultural Sciences, Special Publication 3203, Oakland.

Sys C, Van Ranst E, Debaveye J. 1991. Land evaluation: Part I: Principles in Land Evaluation and Crop Production Calculations. General administration for development cooperation, Brussels. p. $40-80$

Sys C. 1985. Land Evaluation: Parts 1, 2 and 3 (No. Publication No. 352). State University, Ghent. Thomas, G.W. 1982. Exchangeble cations, in: Page, A.L. (Ed.). Methods of Soil Analysis, Part 2: Chemical and Microbiological Properties. Madison, Wisconsin, USA: ASA and SSSA, pp. $159-165$. 
Tripathi BK, Singh M, Narula AM. 1990. Constraint in cotton productivity in India and future strategies for improvement, in: Basu AK, Mannikar ND, Narayanan SS, (Eds.). Cotton Scenario in India. New Delhi, India: ICAR, p. 50-56.

USDA-SCS. 1994. Global Soil Regions. World Soil Resources, Soil Survey Division of the Soil Conservation Service, U.S. Dept. of Agriculture.

Vaidya PH, Pal DK. 2002. Microtopography as a factor in the degradation of Vertisols in central India. Land Degrad Dev. 13:429-445.

Van Ranst E, Tang H, Groenemam R, Sinthurahat S. 1996. Application of fuzzy logic to land suitability for rubber production in Peninsular Thailand. Geoderma. 70:1-19.

Vasu D, Singh SK, Ray SK, Duraisami VP, Tiwary P, Chandran P, Nimkar AM, Anantwar SG. 2016. Soil quality index (SQI) as a tool to evaluate crop productivity in semi-arid Deccan plateau, India. Geoderma. 282:70-79.

Vasu D. Singh SK, Tiwary P, Chandran, P., Ray SK, Duraisami, VP. 2017. Pedogenic processes and soil-landform relationships for identification of yield limiting soil properties. Soil Research. 55:273-284.

Velayutham M, Mandal DK, Mandal C, Sehgal J, 1999. Agro-ecological sub-regions of India for planning and development. NBSS Publ. 35, ICAR- NBSS \& LUP, Nagpur, India.

Wilding LP, Odell RT, Fehrenbacher JB, Beavers AH. 1963. Source and distribution of sodium in Solonetzic soils in Illinois. Soil Sci Soc Am J. 27:432-438.

Wymore AW. 1993. Model-Based Systems Engineering. An Introduction to the Mathematical Theory of Discrete Systems and to the Tricotyledon Theory of System Design. Boca Raton, FL, USA: CRC. 
Zade SP. 2007. Pedogenic Studies of some deep shrink-swell soils of Marathwada region of Maharashtra to develop a viable land use plan (PhD Thesis). P D K V, Akola, Maharashtra, India.

Table 1. General description of the focal study regions.

\begin{tabular}{lrr}
\hline Location & Dhar, Madhya Pradesh & \multicolumn{1}{c}{ Thimmajipet, Telangana } \\
\hline Agro-ecological sub-region ${ }^{1}$ & 5.2 & 7.2 \\
Köppen climate classification & Sub-humid (moist) & Semi-arid (dry) \\
Length of growing period [days] ${ }^{1}$ & $120-150$ & $90-120$ \\
Mean annual rainfall (MAR) $[\mathrm{mm}]^{2}$ & 1100 & 550 \\
Potential evapotranspiration $(\mathrm{PET})^{2}$ & $1500-1800$ & $1600-1800$ \\
Mean annual temperature $\left[{ }^{\circ}{ }^{2}\right]^{2}$ & 25 & 31.5 \\
Soil type ${ }^{3}$ & Typic Haplusterts & Typic Haplusterts \\
& & Sodic Haplusterts \\
Soil moisture regime & Ustic & Ustic \\
\hline${ }^{1}$ after Mandal et al. 2014; ${ }^{2}$ after the Indian Meteorological Department; ${ }^{3}$ USDA soil taxonomy).
\end{tabular}


Table 2. Descriptive statistics for physio-chemical soil properties of soils in Dhar, Madhya

\section{Pradesh}

\begin{tabular}{lrrrrrrr}
\hline Parameters & Min. & Max. & Mean & $\begin{array}{r}\text { Std. } \\
\text { Dev. }\end{array}$ & C V & Skewness & Kurtosis \\
\hline Sand (\%) & 4.1 & 26.6 & 9.3 & 3.8 & 40.7 & 2.74 & 11.50 \\
Silt (\%) & 25.7 & 48.0 & 37.9 & 3.0 & 8.0 & -0.98 & 9.89 \\
Clay (\%) & 12.1 & 60.2 & 47.9 & 10.5 & 21.9 & -2.19 & 4.99 \\
sHC (cm h $\left.{ }^{-1}\right)$ & 0.01 & 1.2 & 0.1 & 0.2 & 136.0 & 3.30 & 13.31 \\
BD (Mg m $\left.{ }^{-3}\right)$ & 1.5 & 1.7 & 1.6 & 0.04 & 2.4 & -0.36 & -0.11 \\
Porosity (\%) & 34.7 & 41.2 & 37.3 & 1.5 & 4.1 & 0.36 & -0.14 \\
AWC (\%) & 9.1 & 16.5 & 13.4 & 1.7 & 12.7 & -0.50 & 0.28 \\
pH (1:2) & 7.6 & 9.0 & 8.2 & 0.3 & 3.6 & 0.59 & 1.10 \\
EC (dS m $\left.{ }^{-1}\right)$ & 0.2 & 0.7 & 0.2 & 0.1 & 46.6 & 1.79 & 2.95 \\
CaCO $(\%)$ & 0.01 & 21.2 & 1.2 & 4.7 & 391.2 & 4.02 & 15.13 \\
OC (\%) & 0.06 & 0.6 & 0.2 & 0.1 & 49.4 & 0.57 & 0.33 \\
CEC (cmol (p+) kg ${ }^{-1}$ ] & 26.1 & 71.3 & 49.7 & 9.2 & 18.6 & -0.22 & 1.02 \\
Clay CEC & 54.7 & 231.7 & 99.4 & 28.6 & 28.8 & 2.98 & 12.65 \\
Base saturation (\%) & 79.8 & 143.1 & 112.5 & 14.9 & 13.2 & -0.11 & -0.50 \\
Ca/Mg & 0.9 & 4.4 & 2.6 & 0.9 & 35.4 & -0.16 & -0.55 \\
ESP & 0.5 & 24.0 & 3.7 & 5.0 & 135.2 & 3.00 & 9.44 \\
EMP & 18.2 & 50.6 & 28.0 & 7.8 & 27.9 & 1.31 & 1.54 \\
\hline
\end{tabular}


Table 3. Descriptive statistics for physio-chemical soil properties of soils in Thimmajipet, Telangana

\begin{tabular}{lrrrrrrr}
\hline Parameter & Min. & Max. & Mean & $\begin{array}{r}\text { Std. } \\
\text { Dev. }\end{array}$ & C V & Skewness & Kurtosis \\
\hline Sand (\%) & 39.5 & 68.1 & 55.6 & 7.9 & 14.2 & -0.48 & -0.57 \\
Silt (\%) & 1.0 & 18.2 & 9.9 & 3.7 & 37.8 & -0.13 & 0.45 \\
Clay (\%) & 19.8 & 52.4 & 34.3 & 8.0 & 23.3 & 0.49 & 0.18 \\
sHC (cm h $\left.{ }^{-1}\right)$ & 0.01 & 0.2 & 0.04 & 0.06 & 161.2 & 2.27 & 4.05 \\
BD $\left(\mathrm{Mg} \mathrm{m}^{-3}\right)$ & 1.2 & 1.5 & 1.3 & 0.06 & 4.6 & 0.72 & -0.22 \\
Porosity (\%) & 42.6 & 51.7 & 48.4 & 2.4 & 5.0 & -0.72 & -0.22 \\
AWC (\%) & 10.6 & 39.4 & 24.2 & 9.3 & 38.4 & 0.21 & -1.44 \\
pH (1:2) & 8.3 & 9.7 & 9.3 & 0.3 & 4.1 & -1.00 & 0.43 \\
EC (dS m $\left.{ }^{-1}\right)$ & 0.1 & 1.6 & 0.9 & 0.5 & 53.3 & -0.18 & -1.50 \\
CaCO ${ }_{3}(\%)$ & 3.7 & 23.8 & 7.8 & 3.6 & 46.3 & 3.42 & 15.40 \\
OC (\%) & 0.08 & 1.6 & 0.4 & 0.3 & 73.9 & 1.92 & 4.63 \\
CEC [cmol (p+) $\mathrm{kg}^{-1}$ ] & 19.5 & 40.2 & 27.6 & 7.4 & 26.8 & 0.53 & -1.35 \\
Clay CEC & 58.7 & 106.2 & 80.5 & 11.5 & 14.3 & 0.51 & -0.30 \\
Base saturation (\%) & 74.8 & 115.6 & 95.7 & 10.1 & 10.6 & -0.23 & -0.54 \\
Ca/Mg & 1.3 & 2.2 & 1.8 & 0.2 & 14.0 & 0.09 & -1.02 \\
ESP & 13.7 & 46.6 & 26.7 & 6.7 & 25.3 & 0.90 & 2.11 \\
EMP & 15.4 & 30.8 & 22.2 & 3.9 & 17.7 & 0.53 & -0.48 \\
\hline
\end{tabular}


Table 4. Differentiating characteristics identified with respect to the soil site suitability for cotton cultivation of the two regions.

\begin{tabular}{lll}
\hline Characteristics & $\begin{array}{l}\text { Dhar } \\
\text { (SHM) }\end{array}$ & $\begin{array}{l}\text { Thimmajipet } \\
\text { (SAD) }\end{array}$ \\
\hline Mean Temperature & $\mathrm{S} 1$ & $\mathrm{~S} 2$ \\
Rainfall & $\mathrm{S} 2$ & $\mathrm{~S} 3$ \\
Length of growing period & $\mathrm{S} 2$ & $\mathrm{~S} 3$ \\
Soil drainage & $\mathrm{S} 2$ & $\mathrm{~S} 1$ \\
Water logging & $\mathrm{S} 2$ & $\mathrm{~S} 1$ \\
Slope & $\mathrm{S} 1$ & $\mathrm{~S} 2$ \\
ESP & $\mathrm{S} 1$ & $\mathrm{~S} 3$ \\
EMP & $\mathrm{S} 2$ & $\mathrm{~S} 3$ \\
& $\mathrm{~S} 2 \mathrm{w}$ & $\mathrm{S} 3 \mathrm{~s} \mathrm{c}$
\end{tabular}

w- moisture /wetness constraints: s-soil related constrains; c-climate related constraints 
Table 5. Weighted soil quality indices, of individual pedons with two depths (0-30 cm and 0-100 cm) using linear scored indicators chosen by principal component analysis minimum data set (MDS) of both study regions

\begin{tabular}{crrrr}
\hline Pedon no. & \multicolumn{3}{l}{ Dhar } & \multicolumn{2}{c}{ Thimmajipet } \\
& $0-30 \mathrm{~cm}$ & $0-100 \mathrm{~cm}$ & $0-30 \mathrm{~cm}$ & $0-100 \mathrm{~cm}$ \\
1 & 0.48 & 0.56 & 0.76 & 0.72 \\
2 & 0.36 & 0.37 & 0.79 & 0.78 \\
3 & 0.56 & 0.48 & 0.67 & 0.68 \\
4 & 0.46 & 0.44 & 0.74 & 0.74 \\
5 & 0.65 & 0.58 & 0.80 & 0.82 \\
6 & 0.54 & 0.50 & & \\
7 & 0.33 & 0.30 & & \\
\hline
\end{tabular}


Table 6. Summary statistics for the soil quality index (SQI)

\begin{tabular}{lcc}
\hline \multicolumn{1}{c}{ Parameters } & Additive & Weighted \\
\hline Mean & 2.82 & $\mathbf{0 . 5 7}$ \\
Standard Error & 0.04 & 0.02 \\
Median & 2.79 & 0.58 \\
Mode & 2.64 & 0.37 \\
Standard Deviation & 0.34 & 0.17 \\
Sample Variance & 0.12 & 0.03 \\
Kurtosis & -0.63 & -1.26 \\
Skewness & 0.26 & -0.11 \\
Range & 1.44 & 0.60 \\
Minimum & 2.18 & 0.27 \\
Maximum & 3.62 & 0.87 \\
Lower limit & 2.14 & 0.23 \\
Upper limit & 3.50 & 0.91 \\
\hline
\end{tabular}


Table 7. Site suitability for cotton production

\begin{tabular}{lll}
\hline Assessment method & Dhar (SHM) & Thimmajipet (SAD) \\
\hline Soil site suitability analysis & Moderately suitable (S2) & Marginally suitable (S3) \\
Soil quality index (weighted) & Low & Moderate to high \\
SQI and yield correlation & Linear model & Linear model \\
& Yield $=538.05$ SQI +81.3 & Yield $=754.86$ SQI -263.4 \\
& $r^{2}=0.83$ & $r^{2}=0.49$ \\
\hline
\end{tabular}




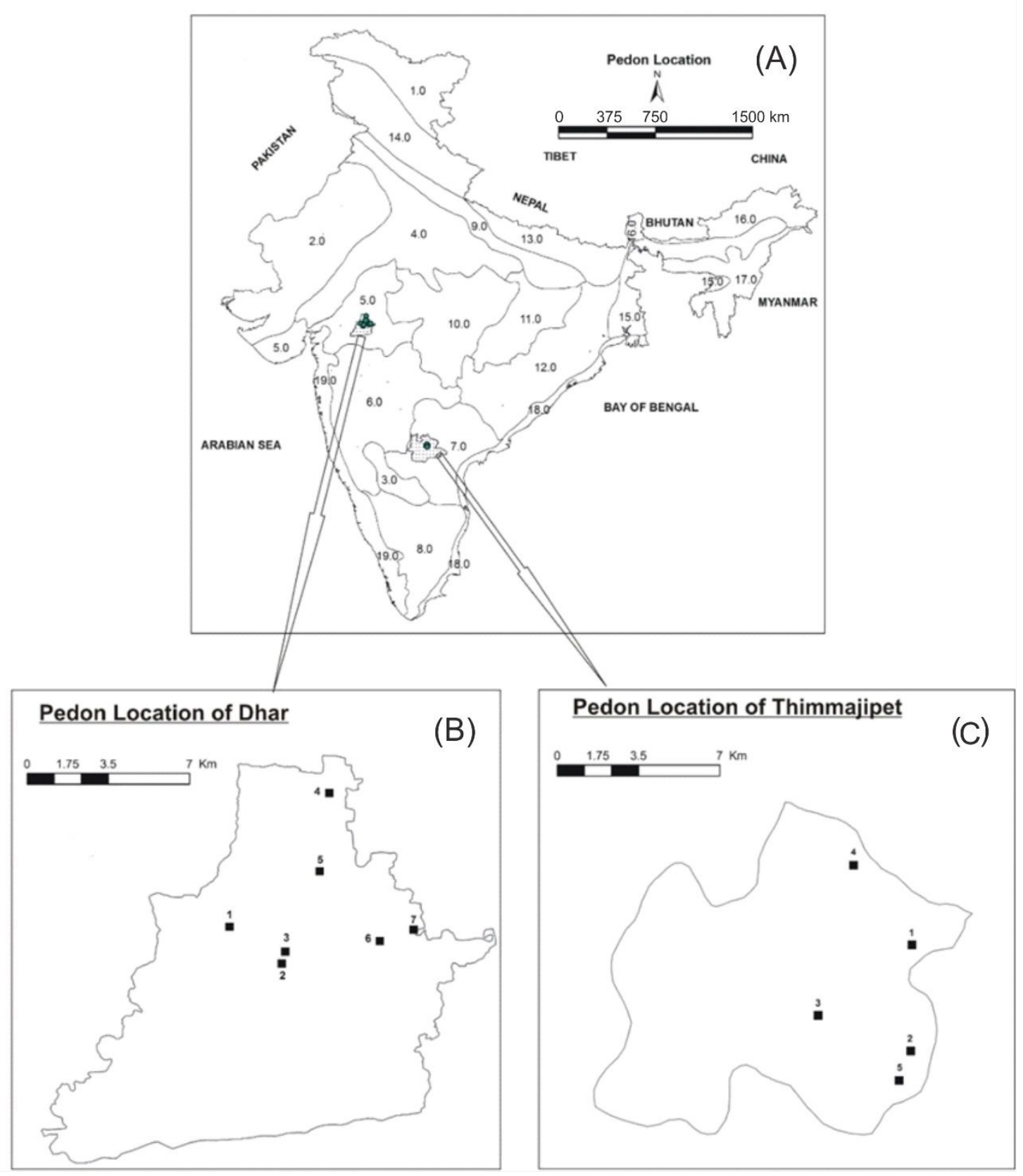

Figure 1. (A) 20 agro-ecological regions of India, The numbers denote the different agroecological regions (after Sehgal, 1991; Velayutham et al. 1999; Mandal et al. 2014), (B) Location of the seven sampling pedons in the Dhar region, and (C) Location of the five sampling pedons in the Thimmajipet region. 


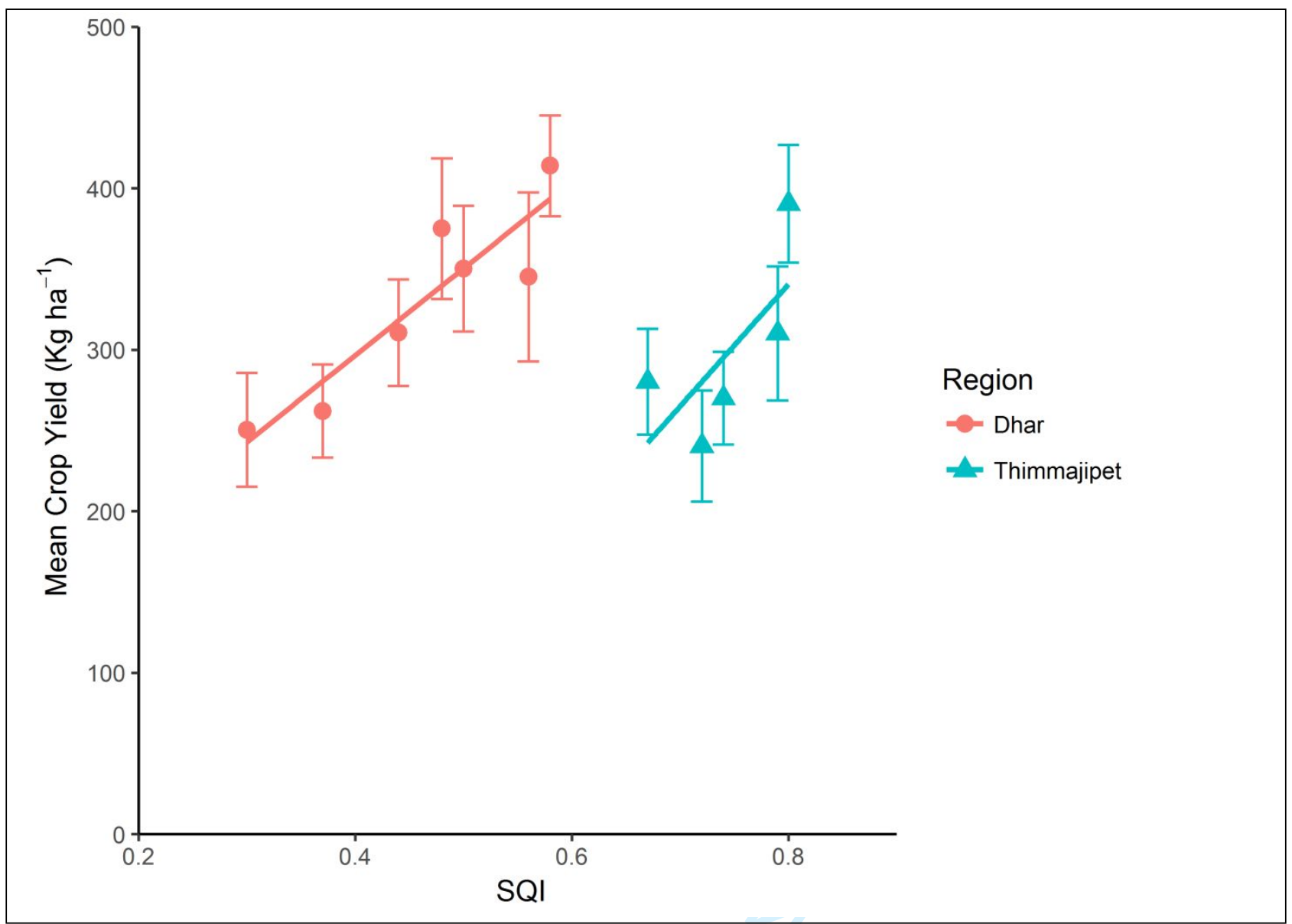

Figure 2. Relationship between weighted index-derived SQI to cotton yield for Dhar and Thimmajipet sites 


\section{Supplementary Information}

Table S1. Location of field sampling sites.

\begin{tabular}{|c|c|c|c|}
\hline Region & Pedon & & Latitude and Longitude \\
\hline \multirow[t]{7}{*}{ Dhar } & D-1 & Sardarpur & $22^{\circ} 40^{\prime} 01^{\prime \prime} \mathrm{N} ; 74^{\circ} 59^{\prime} 10^{\prime \prime} \mathrm{E}$ \\
\hline & $D-2$ & (Rajpura & $22^{\circ} 33^{\prime} 59^{\prime \prime} \mathrm{N} ; 75^{\circ} 07^{\prime} 43^{\prime \prime} \mathrm{E}$ \\
\hline & D-3 & Marol) & $22^{\circ} 35^{\prime} 56^{\prime \prime} \mathrm{N} ; 75^{\circ} 08^{\prime} 18^{\prime \prime} \mathrm{E}$ \\
\hline & D-4 & Kheda & $23^{\circ} 01^{\prime} 59^{\prime \prime} \mathrm{N} ; 75^{\circ} 15^{\prime} 33^{\prime \prime E}$ \\
\hline & D-5 & Dattigara & $22^{\circ} 49^{\prime} 08^{\prime \prime} \mathrm{N} ; 75^{\circ} 13^{\prime} 57^{\prime \prime E}$ \\
\hline & D-6 & Dhar-I & $22^{\circ} 37^{\prime} 40^{\prime \prime} \mathrm{N} ; 75^{\circ} 23^{\prime} 51^{\prime \prime E}$ \\
\hline & D-7 & Dhar -II & $22^{\circ} 39^{\prime} 32^{\prime \prime} \mathrm{N} ; 75^{\circ} 29^{\prime} 24^{\prime \prime E}$ \\
\hline \multirow[t]{5}{*}{ Thimmajipet } & $\mathrm{T}-1$ & Spot 1 & $16^{\circ} 40^{\prime} 26^{\prime \prime} \mathrm{N} ; 78^{\circ} 17^{\prime} 37^{\prime \prime E}$ \\
\hline & $\mathrm{T}-2$ & Spot 2 & $16^{\circ} 37^{\prime} 26^{\prime \prime} \mathrm{N} ; 78^{\circ} 16^{\prime} 37^{\prime \prime E}$ \\
\hline & $\mathrm{T}-3$ & Spot 3 & $16^{\circ} 38^{\prime} 48^{\prime \prime} N$; $74^{\circ} 12^{\prime} 59^{\prime \prime E}$ \\
\hline & $\mathrm{T}-4$ & Spot 4 & $16^{\circ} 43^{\prime} 12^{\prime \prime} \mathrm{N} ; 78^{\circ} 14^{\prime} 34^{\prime \prime E}$ \\
\hline & $\mathrm{T}-5$ & Spot 5 & $16^{\circ} 36^{\prime} 58^{\prime \prime} N$; $78^{\circ} 15^{\prime} 16^{\prime \prime E}$ \\
\hline
\end{tabular}


Table S2. Soil-site suitability criteria (crop requirements) for cotton (Naidu et al. 2006)

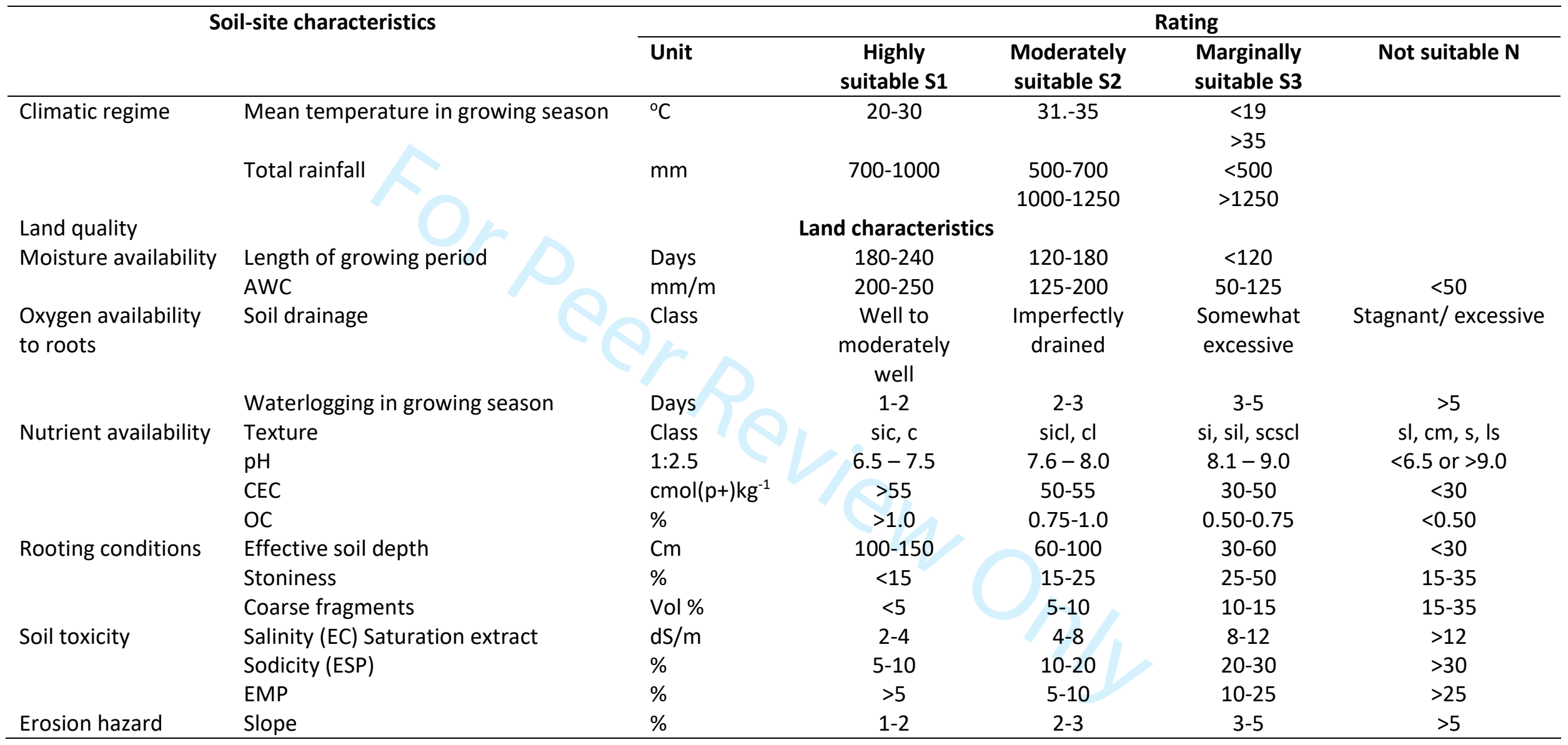

Naidu, L.G.K., Ramamurthy, V., Challa, O., Hegde, R., Krishnan, P., 2006. Manual Soil-Site Suitability Criteria for Major Crops (No. NBSS Publication No. 129). NBSS\&LUPP, Nagpur, India. 
Table S3. Classifications of soil suitability for cotton production

\begin{tabular}{lll}
\hline & Suitability & Limitations \\
S1 & Highly suitable & (with only slight limitations) \\
S2 & Moderately suitable & (moderate limitations) \\
S3 & Marginally suitable & (severe limitations) \\
N & Unsuitable & (major limitations) \\
\hline
\end{tabular}

Table S4. Results of principal component analysis (PCA) of soil quality indicators.

\begin{tabular}{|c|c|c|c|c|}
\hline \multirow[b]{2}{*}{ Parameters } & \multicolumn{4}{|c|}{ Principal component } \\
\hline & PC 1 & PC2 & PC3 & PC4 \\
\hline Total eigen value & 9.062 & 2.159 & 1.807 & 1.259 \\
\hline$\%$ total variance & 53.304 & 12.698 & 10.628 & 7.408 \\
\hline$\%$ cumulative variance & 53.304 & 66.003 & 76.631 & 84.039 \\
\hline Weightage & 0.634 & 0.151 & 0.126 & 0.088 \\
\hline \multicolumn{5}{|c|}{ Rotated component matrix } \\
\hline Sand (\%) & 0.676 & 0.597 & -0.218 & -0.282 \\
\hline Silt (\%) & -0.779 & -0.479 & 0.177 & 0.213 \\
\hline Clay (\%) & -0.196 & -0.864 & -0.135 & 0.175 \\
\hline $\mathrm{sHC}\left(\mathrm{cm} \mathrm{hr}^{-1}\right)$ & -0.183 & -0.035 & 0.907 & -0.061 \\
\hline $\mathrm{BD}\left(\mathrm{Mg} \mathrm{m}^{-3}\right)$ & -0.844 & -0.400 & 0.195 & 0.117 \\
\hline Porosity (\%) & 0.844 & 0.399 & -0.196 & -0.117 \\
\hline AWC (\%) & 0.807 & 0.200 & -0.230 & 0.380 \\
\hline $\mathrm{pH}$ & 0.700 & 0.540 & -0.338 & 0.086 \\
\hline $\mathrm{EC}\left(\mathrm{dS} \mathrm{m}^{-1}\right)$ & 0.743 & 0.235 & -0.247 & 0.090 \\
\hline $\mathrm{CaCO}_{3}(\%)$ & 0.419 & 0.733 & 0.261 & -0.038 \\
\hline OC (\%) & 0.100 & 0.145 & -0.107 & -0.869 \\
\hline CEC $\left[\mathrm{cmol}(p+) \mathrm{kg}^{-1}\right]$ & -0.349 & -0.729 & 0.374 & 0.269 \\
\hline Clay CEC & -0.114 & -0.075 & 0.910 & 0.180 \\
\hline Base saturation (\%) & -0.669 & -0.021 & -0.205 & 0.275 \\
\hline $\mathrm{Ca} / \mathrm{Mg}$ & -0.023 & -0.764 & 0.399 & -0.170 \\
\hline ESP & 0.742 & 0.555 & -0.259 & 0.025 \\
\hline EMP & -0.764 & 0.375 & -0.171 & 0.284 \\
\hline
\end{tabular}

$\mathrm{SHC}=$ saturated hydraulic conductivity 
Table S5. Correlation coefficient between highly weighted variables under different PCs.

\begin{tabular}{|c|c|c|c|c|c|c|c|c|}
\hline PC 1 variables & silt & $\mathrm{BD}$ & porosity & AWC & $\mathrm{pH}$ & $\mathrm{EC}$ & ESP & EMP \\
\hline Silt & 1.000 & & & & & & & \\
\hline$B D$ & $0.672 * *$ & 1.000 & & & & & & \\
\hline porosity & $-0.671 * *$ & $-1.000 * *$ & 1.000 & & & & & \\
\hline AWC & $-0.606 * *$ & $-0.632 * *$ & $0.633^{* *}$ & 1.000 & & & & \\
\hline $\mathrm{pH}$ & $-0.756^{* *}$ & $-0.658^{* *}$ & $0.658 * *$ & $0.643 * *$ & 1.000 & & & \\
\hline $\mathrm{EC}$ & $-0.590 * *$ & $-0.574 * *$ & $0.574 * *$ & $0.558 * *$ & $0.657 * *$ & 1.000 & & \\
\hline ESP & $-0.711 * *$ & $-0.730 * *$ & $0.731^{* *}$ & $0.642^{* *}$ & $0.867^{* *}$ & $0.759 * *$ & 1.000 & \\
\hline EMP & $0.392 * *$ & $0.465 * *$ & $-0.464 * *$ & $-0.381 * *$ & $-0.280^{*}$ & -0.243 & $-0.307^{*}$ & 1.000 \\
\hline PC 2 Variables & clay & $\mathrm{CaCO} 3$ & $\mathrm{Ca} / \mathrm{Mg}$ & & & & & \\
\hline Clay & 1 & & & & & & & \\
\hline $\mathrm{CaCO} 3$ & $-0.726 * *$ & 1 & & & & & & \\
\hline $\mathrm{Ca} / \mathrm{Mg}$ & $0.464^{* *}$ & $-0.360 * *$ & & & & & & \\
\hline PC 3 Variables & $\mathrm{sHC}$ & Clay CEC & & & & & & \\
\hline $\mathrm{sHC}$ & 1 & & & & & & & \\
\hline Clay CEC & $.798 * *$ & & 1 & & & & & \\
\hline
\end{tabular}

